\title{
Improving The Motivation and Learning Outcomes Students with Applying "Everyone Is Teacher Here" Learning Method
}

\author{
Eko Triatmojo Wibowo \\ Yuli Agustina \\ Program Studi Administrasi Perkantoran Universitas Negeri Malang \\ E-mail: yuli.agustina .fe @ um.ac.id
}

\begin{abstract}
This research aims to know the improvement of learning outcome and learning motivation of students by using Everyone Is Teacher Here learning method. This research was included into Classroom Action Research which conducted on 2 cycles in which each cycle consists of 2 meetings and 4 stages. The $12^{\text {th }}$ Grade of Office Administration SMK PGRI 6 Malang for 27 students as research subject. Data of learning outcome obtained from post-test and data of student learning motivation obtained from questionnaire. The research result showed average score of cognitive and affective learning outcome was increase significantly as well as student learning motivation in the category of very satisfying. The research result explained that Everyone Is Teacher Here learning method proven to improve learning outcome and learning motivation of students. It is suggested to the teachers to apply this method, especially to the active learning focuses on student.
\end{abstract}

Keywords: Everyone Is Teacher Here Method, Learning Motivation, Learning Outcome

Education is an important factor in the development of a nation. Because education is a long-term investment that has an important key in improving the quality of human resources quality and become a progress factor of a country. Quality and continuous education produces a high quality of human resource. School as an educational institution to be a good place in the intellectual life of the nation in addition to other activities in the name of education.

SMK PGRI 6 Malang is domiciled in Jalan Janti Selatan No.100 is an educational institution that implements the 2013 curriculum. Some problems encountered after the researchers made observations with teachers subjects Personnel Administration namely 1) students tend to be passive and less participative when teachers explain using conventional model of lecture, 2) during the discussion and presentation of students tend to perform activities outside the lesson and depend on someone in the group.

With these various problems then triggered some learning methods that involve more students in the learning process. Active role of students in teaching and learning activities can foster a high curiosity and increase student motivation in solving problems given to him. Schunk, Pintrich, and Meece (2012: 6) argue that motivation demands physical and mental activity. Physical activity requires effort, persistence, and other observable actions. Mental activity includes various cognitive 
actions such as planning, memorization, organizing, monitoring, problem solving, and progress assessment.

Penelitian Tindakah Kelas (PTK) is the right strategy to apply the methods and models of learning that students are interested in. Mentioned in Ekawarna (2009: 10-11) the purpose of conducting Penelitian Tindakah Kelas (PTK) is in order to improve the ways of teaching through the application of new methods or new actions found and believed because the new method has been tested and effective in improving learning outcomes As expected. In this case the researchers chose the method Everyone Is Teacher Here .According Djamarah (2010: 397) active learning methods Everyone Is Teacher Here is a very appropriate strategy to obtain the participation of students as a whole and individually. This strategy provides opportunities for learners to play a role as teachers for their friends.

The steps of learning according to Warsono and Hariyanto (2013: 46-47) are:

a) Share all index cards to each student in the class;

b) Ask students to write down the most recently learned questions from the field of study the teacher has just taught. Questions should be brief and clear and logically acceptable;

c) Collect the index card or question card and the teacher scrambles all the cards to mix and the students do not get their own questions;

d) Then each index card is distributed and given time to think about the answers that are then presented in front of the class;

e) After enough time, the teacher tries to ask the volunteer students to come forward presenting their answers individually and the other students are given the opportunity to refute or add to the answer;

f) The activity continues until all students finish presenting their answers and the teacher and the students make a conclusion together.

Excess methods Everyone Is Teacher Here are 1) to stimulate the creativity of the students in the form of an idea or ideas in making questions and answers questions and respond to answer a friend to broaden your horizons, 2) develop respect for each other's answers and tolerance if there are different answers, 3) stimulate students To conduct individual learning activities, 4) this method can generate student's learning motivation so that it can have a positive effect on student learning outcomes, 5) the level of student achievement in addition can be seen from the value of test results can also be seen From how students respond to questions and answers, so that they can actually connect the material, understand and live and practice in everyday life.

\section{METHOD}

The type of research used in this research is Penelitian Tindakah Kelas (PTK). Arikunto, Suhardjono, and Supardi (2014: 105) argue that "Class Action Research is an approach to improving education by making changes toward improvements in educational outcomes and learning." This study was conducted in two cycles. Each cycle consisted of two meetings, the first meeting in each cycle was conducted by Everyone Is Teacher Here, and in the second meeting conducted posttest activities. 
This research was conducted in class XII APK SMK PGRI 6 Malang which addressed at Jalan Janti Selatan No.100 Malang. The study was conducted from January to February 2017 in the academic year 2016/2017. The researcher is assisted by 3 observers, so that the learning action can be observed in detail and nothing is missed. With the observer also ensure the accuracy of collected data that is considered important in solving research problems.

Source of research data obtained from subject teachers of Personnel Administration, observation sheets filled out by the observers, the data through questionnaires learning motivation, learning outcomes through the Posttest cognitive and affective through RPP assessment sheet. Previous cognitive learning outcomes have been tested for difficulty and differentiation. Data of affective learning results obtained through the assessment sheet in RPP that contains 3 aspects of Discipline, Responsibility and Compensation. Questionnaire of learning motivation consists of 6 indicators according to Uno (2011: 23) that is 1) the desire and desire succeed, 2) the encouragement and the need in learning, 3) the existence of hope and the future aspiration, 4) the existence of awards in learning, 5 ) the existence of interesting activities in learning, and 6) the existence of a conducive learning environment, allowing someone students can learn well.

\section{RESULT \& DISCUSSION}

\section{Result}

Before making the observations and interviews of subject teachers, researchers first ask permission to the school. Through the interview and observation activities the researcher asks the subject teacher about the process undertaken during this time and the condition of the students at the time of the learning took place. According to the information from the subject teachers students in the classroom tend to be lazy and less eager in following the lesson, for the activity is still not many students who participate and other students are not focused on the lessons even there are students sleeping in the classroom. For the students' motivation level according to the teacher's information and the observation of the class, the researcher did not reach the good value with $49 \%$ result including the criterion "very unsatisfactory".

Implementation of the first cycle action was conducted twice on Thursday, January 19, 2017 and Friday, January 20, 2017. Each meeting consists of 3x45 minutes.Observation of cycle I action is carried out during the learning process. The activities observed were field notes, student activities, teacher activities, and the success of learning methods Everyone Is Teacher Here.

Results in the first cycle, field notes at the first meeting there were three students who do not attend. Teachers can master the class well but there are still students who make noise. There are 10 students who lack concentration. The result of student activity observation is at an average value of $83 \%$. The observation of teacher activity is at an average of $85 \%$. Results eith the success of learning methods that are in the average value of $64 \%$. Student motivation questionnaire results reached an average of $81 \%$. The average cognitive learning outcome was 79.6 and the affective learning outcome was $65 \%$. 
In cycle II, the first meeting there were 7 students who did not enter. Students look more conducive and more listen to teachers and friends during the presentation, students are more actively asked, teachers can control the class better, still seen some rowdy students. Student activity observation results are at an average of $93 \%$. The observation of teacher activity is at an average of $92 \%$. Results eith the success of learning methods that are in the average value of $83 \%$. Student motivation questionnaire results reached an average of $83 \%$. The average cognitive learning outcome was 83.2 and the affective learning outcome was 79\%. Data from two cycles of exposure proved Learning Methods Teacher Is Here Everyone managed to improve learning outcomes and the level of student motivation.

\section{Discussion}

According to subject teachers who become obstacles in the subject of Personnel Administration is the student's motivation of the material discussed, especially in the matter of Marriage and Marriage Report. The amount of material that must be understood to make the condition of students quickly bored and not excited. Teachers informed that the students of class XII APK need an innovation that makes students do not tend to passive. Pratomo, Rosyidi, \& Karyanto (2012) "In classroom learning the teacher should be able to create a good learning atmosphere through the provision of adequate learning facilities for learners, so that students can be more active when learning activities are underway".

Learning materials used in cycle I is "Understanding marriage and marriage Report", while in cycle II is "Understanding divorce and Report divorce". The time allocation used in each meeting is $3 \times 45$ minutes. Activities undertaken in each cycle include 4 stages of planning, action implementation, observation, and reflection. Planning includes coordination with subject teachers, preparing RPP, determining learning objectives, preparing observation sheets of teacher activities, student activities, method success, and field notes.

Implementation of the action includes, delivery of learning objectives and describes learning scenarios by applying Everyone Is Teacher Here, presenting the material as a prefix, distribute paper to write down any questions the students that will be answered at the front after the paper is encrypted, and the teacher calls students one by one to present the answer According to the question paper that students can. Teachers with learners summarize the material and re-explain the student's answers that have not been right. At this stage, it is observed that the situation during the learning takes place based on the observation sheet. The reflection stage is done at each end of the cycle to know the shortcomings of the learning that has been applied based on the data obtained then processed and analyzed for later use in cycle II.

At the end of every cycle carried out activities of post-test to determine the level of students' understanding of the material that was submitted. Zebua \& Siswanto (2014) describes the "Post-test is a learning achievement test given to students after learning on a range of materials is completed to determine the development of the learning ability of students after attending". The results showed 
that the learning methods Teacher Is Here Everyone who applied are in accordance with the implementation steps of learning methods Everyone Is Teacher Here.

Implementation of learning on the subject of Personnel Administration has been running smoothly and in accordance with the RPP and increased. This is shown by the result of increased motivation to learn and learning outcomes. Responses indicated students towards learning method Everyone Is Teacher Here are very good, this is in accordance with the results of a questionnaire which states that follow the learning method Everyone Is Teacher Here can help the students to understand the material that the students feel dull and enhance student motivation, students were enthusiastic and happy With this method of learning because they can learn as a teacher and train the courage to express opinions in the form of answers. Active learning centered on students also poses a student's critical effect on the answers raised by other students who are presentations, the students are interested in asking the unintelligible so as to prevent misunderstanding. Sesen \& Tarhan (2010) also revealed "This situation demonstrates the positive effects of active learning applications based on constructivism to improve students 'learning power, preventing misunderstanding and improving students' thinking skills such as analysis, linking, synthesis, cognitive thinking analytically contrasting with conventional approaches".

Difficulties encountered in learning methods Everyone Is Teacher Here one is to condition students to focus on the subjects being discussed. The solution is to form students into group shapes and better control the activities of students in the classroom. Amran, Yokohama \& Nishino (2016) "Students who contribute to group discussions focus time on developing their ideas that are influenced by their previous experiences on the topic of learning". Also explained by Dwi \& Asto (2013) "the need for mastery of the class, the participation of students in learning and the atmosphere of the class to always be fun".

Motivation examined in this study centered on the interest of students to the Everyone Is Teacher Here method who applied for two cycles. Measuring the level of motivation of students is given through the questionnaire sourced in 6 (six) indicators in which 1) The existence of desire and desire succeeded, 2) The existence of encouragement and needs in learning, 3) Presence of expectations and ideals of the future, 4) In learning, 5) The existence of interesting activities in learning, 6) The existence of a conducive learning environment, allowing a student to learn well. Pratomo, Rosyidi, \& Karyanto (2012) "The questionnaire technique is used to retrieve learning motivation data".

The results of this study indicate that student learning motivation has increased from the initial motivation, cycle I and cycle II. These results occur because students begin to adapt and find interesting things in the Everyone Is Teacher Here Learning Method. In the interviews the students also explained that the students were interested in presenting the answers and asking questions to other students. In the initial motivation of the average student motivation worth D with the category of Very unsatisfactory, the results of initial motivation used as a reference in the measurement of learning motivation in cycle I. Improvement due to the level of student activeness in learning increases, students are more daring in supporting the answers of other students and reveal Ideas that he thinks are true. Yajma, Hayakawa \& Kashiwaba (2016) also agree that "Active learning is 
effective for student motivation because students can share things that approach their goals".

The independence in this method of learning is particularly emphasized when students try to make inquiries and answer questions they can ". Zebua \& Siswanto (2014) "Teachers should apply cooperative learning model because students will be more active and independent in learning and can boost the cooperation of students".

The success criteria of the method used for the measurement of learning outcomes is KKM established by the school. KKM established by SMK PGRI 6 Malang on the subject of Personnel Administration for 75. The learning outcomes of cognitive aspects of students have increased compared with the results of the last test score subjects of Civil Service Administration.

Can be explained that when the subject teachers give the same material using conventional methods and implement remedial value is used as an initial value to researchers, it can be seen giving Learning Methods Teacher Is Here Everyone can improve student learning outcomes. Dwi \& Asto (2013) also argues "that a group of student learning outcomes that are subjected to use active learning model Everyone Is Teacher Here the result is better than a group of student learning outcomes that are subjected to conventional learning model". Increase was due to the application of Everyone Is Teacher Here method that requires students dared to answer and ask students the material that has not been fully understood. Primary and Muslim (2013) "Application of Everyone Is Teacher Here Learning is one way to improve the learning process more efficient and improve learning outcomes and the social skills of students".

The types of affective learning outcomes appear in students in various behaviors such as attention to learning, discipline, learning motivation, respect for teachers and classmates, study habits, and social relationships. In cycle II students begin to understand the course of learning and the steps to be implemented, the classroom atmosphere in cycle II looks more conducive and active along with the many refutations and questions asked students. The result of study is in accordance with research Zebua \& Siswanto (2014) that is "student affective learning achievement very good / Good to $100 \%$ in cycle II".

Everyone Is Teacher Here Active Learning Methods also proved to be effectively used in the classroom that focus on the ability of students in the learning process and learning outcomes are achieved. Hamouda \& Tarlochan (2015) also agree that "Active learning methods that have been used proved to be an effective method that significantly improved student achievement and impacted on improving student learning on learning outcomes".

\section{CONCLUSION \& SUGGESTION}

\section{Conclusion}

Conclusion that the application of learning methods Everyone Is Teacher Here on the subjects of material Personnel Administration Definition of marriage and marriage reports in accordance with lesson plans and students can receive good learning methods Everyone Is Teacher Here and understand the course of learning 
scenarios. The level of student motivation can be increased by the application Everyone Is Teacher Here method. The results of cognitive and affective learning have been shown to increase.

\section{Suggestion}

Referring to the results of this study, teachers are encouraged to provide innovations in implementing the learning activities one is to apply the appropriate learning methods and in accordance with the purpose of learning and focus on students as Everyone Is Teacher Here. The intensity of learning and practice of students is further improved to achieve the learning objectives well.

\section{REFERENCES}

Amran, R., Yokoyama, F., \& Nishino, K. 2016. Development of Active Learning Methodsof English in Japanese High Schools to Support Student Activities in Group Discussions, 96(2016). (Online), (http://www.sciencedirect.com/science?_ob=ArticleListURL\&_method=list\& ArticleListID=$1193818182 \& \_$sort $=r \& \_s t 13 v i e w=c \& m d 5=115$ dsearchtype $\left.=a\right)$, diakses 2 Mei 2017.

Arifin, Z. 2013. Evaluasi Pembelajaran: Prinsip, Teknik, Prosedur. Bandung: Remaja Rosdakarya.

Arikunto, S, Suhardjono, \& Supardi. 2014. Penelitian Tindakan Kelas. Jakarta: Bumi Aksara.

Dimyati dan Mudjiono. 2006. Belajar dan Pembelajaran. Jakarta: Bandung Alfabeta.

Djamarah, S.B. 2010. Guru \& Anak Didik Dalam Interaksi Edukatif. Jakarta: Rineka Cipta.

Dwi, K.F., \& Asto, B.I.G.P. 2013. Pengaruh Pembelajaran Aktif Everyone Is Teacher Here Terhadap Hasil Belajar Siswa Pada Standar Kompetensi Menerapkan Dasar-Dasar Digital Kelas X TAV 1 di SMK Negeri 1 Madiun, 2(1). (Online), (http://id.portalgaruda.org/index.php?ref=browse\&mod=viewarticle\&articl e=64799), diakses 1 Januari 2017.

Ekawarna. 2009. Penelitian Tindakan Kelas. Jakarta: GP. Press.

Faiz, A.M., \& Rakhmawati, L. 2015. Pengaruh Strategi Pembelajaran Aktif Tipe Everyone Is Teacher Here Terhadap Hasil Belajar Siswa Pada Mata Pelajaran Elektronika Dasar Kelas X TAV di SMK Negeri 7 Surabaya, 4(3). (Online), (http://ejournal.unesa.ac.id/article/16519/44/article.pdf.), diakses 2 Januari 2017. 
Hamalik, O. 2006. Proses Belajar Mengajar. Jakarta: Remaja Rosdakarya.

Hamuoda, A.M.S., \& Tarlochan, F. 2015. Enganging Engineering Student in Active Learning and Critical Thinking trough Class Debates, 191(2015). (Online), (http:/www.sciencedirect.com/science?_ob=ArticleListURL\&), diakses 2 Mei 2017.

Kunandar. 2010. Langkah Mudah Penelitian Tindakan Kelas Sebagai Pengembangan Profesi Guru. Jakarta: Raja Grafindo Persada.

Pratama, A.S, \& Muslim, S. 2013. Pengaruh Pembelajaran Kooperatif Tipe Everyone Is Teacher Here Terhadap Hasil Belajar Siswa Pada Standar Kompetensi Menafsirkan Gambar Teknik Listrik di SMK Negeri 2 Surabaya, 2(2). (Online), (http://id.portalgaruda.org/index.php?ref=browse\&mod=viewarticle\&articl e=102765), diakses 2 Januari 2017.

Pratomo, E.N., Rosyidi, A., \& Karyanto, P. 2012. Hasil Belajar Biologi Ranah Kognitif Ditinjau Dari Model Everyone Is Teacher Here dan Minat Belajar Siswa Kelas XI di SMA Negeri 1 Sukoharjo, 4(3). (Online), (http://jurnal.fkip.uns.ac.id/index.php/bio/article/view/1427), diakses 2 Januari 2017.

Schunk, D.H., Pintrich P.R., \& Meece J.L. 2012. Motivasi Dalam Pendidikan: Teori, Penelitian, dan Aplikasi. Jakarta: PT Indeks.

Sesen, B.A., \& Tarhan, L. 2010. Promoting Active Learning in High School Chemistry: Learning Achievement and Attitude, 2(2010). (Online), (http://www.scienedirect.com/science? on=ArticleListURL\& method=list\& ArticleListID), diakses 2 Mei 2017.

Slameto. 2010. Belajar dan Faktor-Faktor yang Mempengaruhinya. Jakarta: Rineka Cipta.

Sudjana, N. 2006. Penilaian Hasil Proses Belajar Mengajar. Bandung: Remaja Rosdakarya.

Sugiyono. 2015. Metode Penelitian Pendidikan (Pendekatan Kuantitatif, Kualitatif, dan $R \& D$ ). Bandung: Alfabeta.

Undang-Undang RI No. 20 Tahun 2003 tentang Sistem Pendidikan Nasional.

Universitas Negeri Malang. 2015. Petunjuk Pelaksanaan Praktik Pengalaman Lapangan (PPL) Keguruan Universitas Negeri Malang. Malang: Pusat Pengembangan Program Pengalaman Lapangan.

Universitas Negeri Malang. 2010. Pedoman Penulisan Karya Ilmiah. Malang: Universitas Negeri Malang. 
Uno, B.H. 2011. Teori Motivasi dan Pengukurannya. Jakarta. Bumi Aksara.

Warsono, \& Hariyanto. 2013. Pembelajaran Aktif: Teori dan Asesmen. Bandung: PT Remaja Rosdakarya.

Yajma, K., Hayakama, Y., Kashiwaba, Y., Takahshi, A., \& Oiguchi, S. 2016.

Construction of Active Learning Environment by the Student Project, 96(2016). (Online),

(http://www.sciencedirect.com/science? ob=ArticleListURL\& method=list\& _ArticleListID=-), diakses 2 Mei 2017.

Zebua, T.P., \& Siswanto. 2014. Penerapan Kolaborasi Pembelajaran STAD dan Everyone Is Teacher Here Untuk Meningkatkan Prestasi Belajar, 12(1). (Online), (http://journal.uny.ac.id/index.php/jpakun/article/view/5163), diakses 20 November 2016. 